\title{
Persistence of biodiversity in a dryland remnant within an intensified dairy farm landscape
}

\author{
Mike H. Bowie ${ }^{1, *}$, Lesley Black ${ }^{1}$, Stephane Boyer ${ }^{1,2,3}$, Nicholas M. Dickinson ${ }^{1}$, Simon Hodge ${ }^{4}$ \\ ${ }^{1}$ Department of Ecology, Lincoln University, Lincoln 7647, Canterbury, New Zealand \\ ${ }^{2}$ Department of Natural Sciences, Faculty of Social and Health Sciences, Unitec Institute of Technology, 139 Carrington Road, \\ Mt Albert, Auckland 1025, New Zealand \\ ${ }^{3}$ Bio-Protection Research Centre, PO Box 85084, Lincoln University, Christchurch 7647, New Zealand \\ ${ }^{4}$ Department of Agricultural Sciences, Lincoln University, Lincoln 7647, Canterbury, New Zealand \\ *Author for correspondence (Email: Mike.bowie@lincoln.ac.nz)
}

Published online: 28 August 2015

\begin{abstract}
The lowland Canterbury Plains of New Zealand have been extensively modified since human occupation, but with recent conversions to irrigated dairy farming very few remnants of native dryland vegetation remain in the region. We investigated soil chemistry, plant distribution and soil invertebrates along transects in Bankside Scientific Reserve, a small (2.6 ha) remnant. The vegetation is a mosaic of native woody shrubs, predominantly Kunzea serotina (kanuka, Myrtaceae) and Discaria toumatou (matagouri, Rhamnaceae), and dry grassland. Changed soil conditions appear to have made the reserve less conducive for native species, but better suited to invasion by exotic plants. Compared with detailed surveys before the dairy conversion, only $31 \%$ of the original 65 native vascular plant species were recorded in the present study and 27 new exotic species had arrived since the original survey. Soil nutrient concentrations and $\mathrm{pH}$ were lower in the reserve than in surrounding farmland; peaks of nitrate and ammonium were recorded at the boundary. Soil phosphate was elevated in lower-lying areas within the reserve, an effect associated with natural drainage channels and evident up to $20 \mathrm{~m}$ into the reserve. Four species of native megascolecid earthworms were found in the reserve but not in neighbouring pasture, whereas the diversity and abundance of beetles and spiders in the reserve was similar to that observed at least $10 \mathrm{~m}$ into surrounding farmland. This study highlights the importance of the soil environment in sustaining biodiversity. We conclude that this remnant retains valuable communities of native species, but is apparently being impacted by phosphate encroachment and habitat fragmentation. This does not appear to be an intractable management issue for the interface between agricultural systems and conservation sites within a dairy landscape mosaic. We suggest that attention is required to maintain buffer zones adjacent to small, isolated and vulnerable remnants of original biota that are surrounded by intensive agriculture.
\end{abstract}

Keywords: conservation; kanuka; Kunzea; nutrient enrichment; threatened species; earthworms

\section{Introduction}

The conversion of natural ecosystems to agricultural land is one of the main causes of native biodiversity loss (Tilman et al. 2001). New Zealand is now the world's largest dairy exporter, with dairy products accounting for $60 \%$ of New Zealand's agricultural exports (Thorburn et al. 2012). There has been a significant conversion from dryland sheep farming to irrigated dairy farming in recent years, particularly on the Canterbury Plains of South Island. This province contains $20 \%$ of New Zealand's farmland, with an increase of 194000 dairy cattle between 2011 and 2012 (Agriculture and the New Zealand Economy, 2014).

Lowland Canterbury has a temperate climate and moderate rainfall (c. $630 \mathrm{~mm}$ ). Shallow, stony, well-drained soils are an important feature of the landscape (Molloy 1998). Drier areas, including the present study site, typically support tussock grassland (Festuca novae-zelandiae) and Danthonia grassland with a few species of woody shrubs (Ward et al. 1964; Molloy 1970). By the end of the 19th century, most of the Canterbury Plains had been ploughed and sown in crops or pasture (Winterbourn et al. 2008). The region has been described as the most modified and biologically depauperate lowland environment in New Zealand due to the prevalence of agriculture (Brockerhoff et al. 2008); less than $0.5 \%$ of the original vegetation type remains within the Low Plains Ecological District (Ecroyd \& Brockerhoff 2005) and this dry scrubland/grassland mosaic is now an acutely threatened land habitat (Walker et al. 2006; Head \& Given 2001; Meurk 2008). Most of the natural remnants that exist are considered too small, fragmented and isolated to maintain the biodiversity that was once present (Meurk et al. 1995; Bretherton \& Given, 2002; Meurk 2008). Extensive and rapid conversion to centre pivot spray irrigation and more intensive farm management systems has also raised environmental concerns about water use, fertiliser input, waste management and nitrogen and phosphorus enrichment of water bodies (Di \& Cameron 2002; Houlbrooke et al. 2004; Clark et al. 2007; Ballantine \& Davies-Colley 2013). There is now considerable interest in restoration of native biodiversity within this landscape (Meurk \& Swaffield 2000). For example, the importance of invertebrates to ecosystem services in agricultural landscapes is becoming better appreciated, including their value in facilitating soil structure, functionality, pollination, biocontrol and seed dispersal (Keesing \& Wratten 1998). However, the residual and continuing impact of adjacent agronomic practices on the few remaining remnants of the original dryland habitat in Canterbury is largely unknown. 
The aims of the present study were to (i) identify the current conservation value of one of the few dryland reserves remaining on the lowland Canterbury Plains, (ii) assess the persistence of native biodiversity within this small (2.6 ha) nature reserve within an agricultural matrix, and (iii) evaluate the effects of the likely infringement of irrigation water and nutrients from adjacent farmland.

\section{Materials and methods}

\section{Site description}

Bankside Scientific Reserve $\left(-43.730^{\circ} \mathrm{S} 172.156^{\circ} \mathrm{E} ; 65-69 \mathrm{~m}\right.$ asl.) consists of a 2.6-ha remnant of dryland vegetation and is one of only a few dryland reserves remaining on the lowland Canterbury Plains (Meurk et al. 1995). The original vegetation was probably subjected to burning by Māori for hundreds of years, then reseeded and fertilised by European settlers and subsequently sheep-grazed from the mid-19th century until recent decades. The Bankside site was designated a scientific reserve in 1969 and was purchased by the Crown in 1971 (Voice 1980; Williams 2005).

The reserve (Fig. 1) is adjoined by an unsealed road on the eastern side and otherwise is surrounded by irrigated dairy pasture. Soils in this region have developed on river floodplain gravel fans with undulating relief that includes stone and sand ridges, flat areas and depressions that represent abandoned stream channels (Voice 1980). The shallow Eyre soils are very stony, nutrient poor, well-drained sandy loams that are prone to drought (Molloy 1970, 1998). The site supports a vegetation cover of dry grassland consisting of mixed assemblages of exotic and indigenous species interspersed with areas of xerophytic woody shrubs, mostly Kunzea serotina (kānuka, Myrtaceae) and Discaria toumatou (matagouri, Rhamnaceae). The flora of this site has been studied twice previously: Molloy (1970) provided a detailed catalogue of the flora, listing 66 native vascular plant species, and Jenson \& Shanks (2005) completed a one-day reassessment of the site, but recorded only 14 native species. The adjacent dairy pasture is a ryegrass/ white clover mix and is fertilised with sulphur superphosphate, urea, potash, lime, and cattle slurries.

\section{Sampling transects}

Nine transects extending from the pasture into the reserve were aligned to provide three transects each on land of three elevations: low-lying (mean altitude $65 \mathrm{~m}$ asl.), intermediate (67 $\mathrm{m}$ asl.) and higher (69 $\mathrm{m}$ asl.) (Fig. 1). Topography was measured at each sampling point using a Trimble Differential GPS. Along each of the nine transects, sampling points ranged from $10 \mathrm{~m}$ within the dairy paddock, then into the reserve at distances of $0,2.5,5,10,20,40,60,80 \mathrm{~m}$ from the fence-line. Transects were $15 \mathrm{~m}$ or more apart.

\section{Soils and plants}

Three soil cores $(15 \mathrm{~mm}$ diameter $\times 10 \mathrm{~cm}$ depth $)$ were extracted within $1 \mathrm{~m}^{2}$ of each sampling point and bulked for

Figure 1. Aerial photograph of Bankside Scientific Reserve showing dominant kānuka, matagouri dotted at the north end and greener low-lying areas draining from pasture (a) and elevation map and location of sampling transects (b).

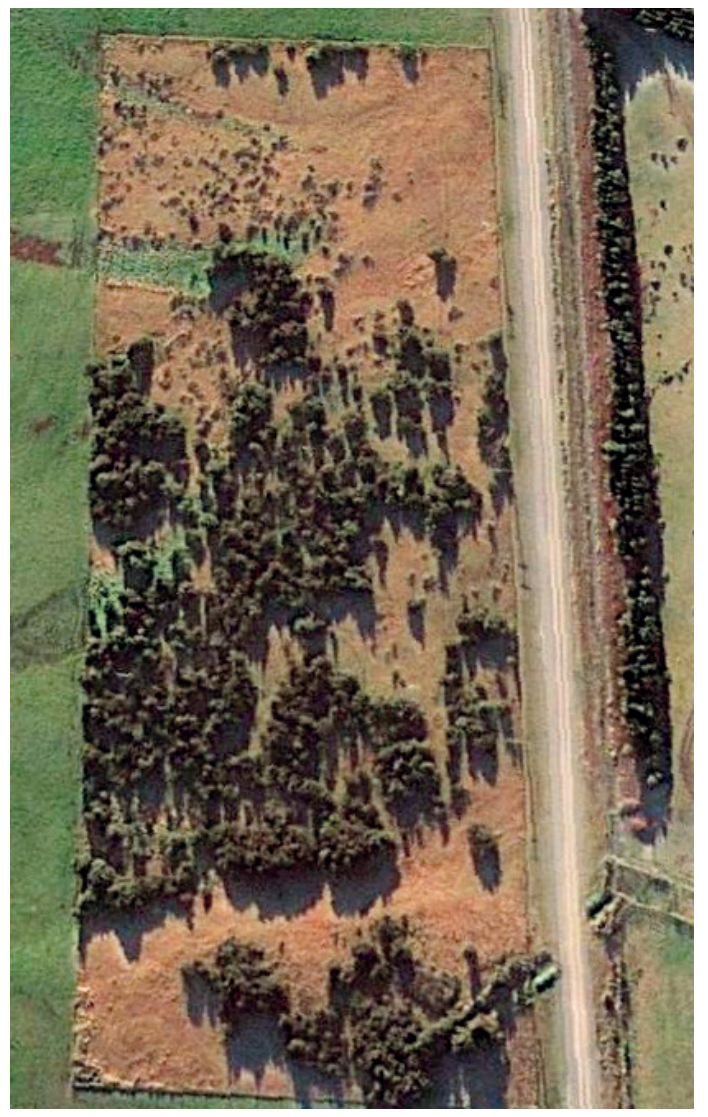

(a)

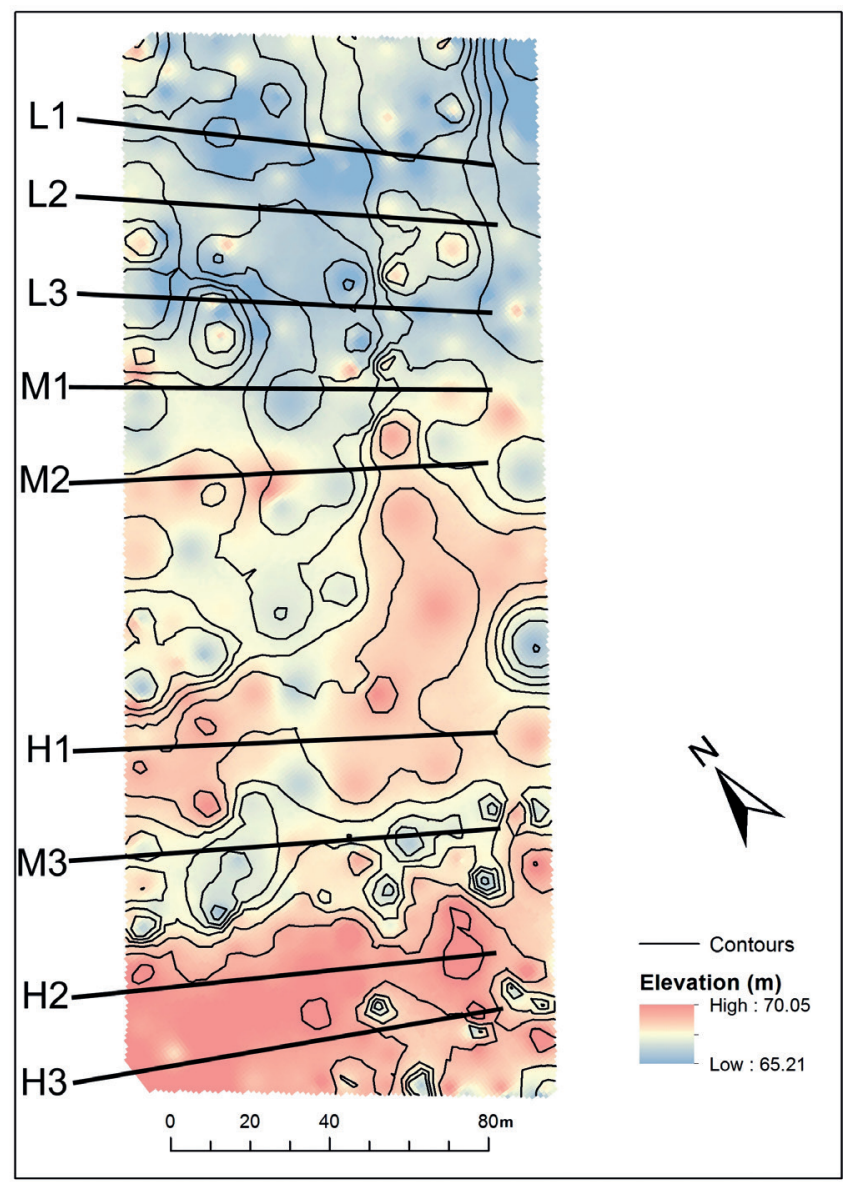

(b) 
later chemical analysis. Using fresh soil, $\mathrm{pH}, \mathrm{KCl}$-extractable nitrate and ammonium, and Olsen P were analysed by Analytical Services in the Department of Soil and Physical Sciences at Lincoln University, using standard methodologies (see Blakemore et al. 1987).

The percent ground cover to $1 \mathrm{~m}$ in height was estimated using a $50 \times 50 \mathrm{~cm}$ quadrat centred on each sampling point. A plant species inventory was recorded within a 5-m diameter of each sampling point in three height categories $(<1 \mathrm{~m}, 1-2 \mathrm{~m}$, $>2 \mathrm{~m}$ ). In addition to these plots, the whole reserve was surveyed to account for different species' phenologies and record as many plant species as possible over 15 days between April and December 2012, taking in excess of 100 personhours. Plant species encountered by Molloy (1970) and Jenson and Shanks (2005) were compared with the current study to estimate changes in flora over time. The Jenson and Shanks (2005) plant survey corresponds to an eight person-hour search undertaken on 24th May 2005. Plant nomenclature follows that used by Molloy (1970), apart from where names are known to have changed.

\section{Invertebrates}

Soil cubes $(20 \times 20 \times 20 \mathrm{~cm})$, including the vegetation and leaf litter, were dug with a spade at each sampling point and then carefully sorted on plastic sheets, separating all earthworms, beetles and spiders for later identification.

Earthworms were initiallyidentifiedas exotic(Lumbricidae) or endemic (Megascolescidae) based on external morphology (Lee 1959) and then classified into different recognisable taxonomic units (RTUs) (Boyer \& Wratten 2010). Tissue samples were collected from representatives of each RTU and molecular analyses conducted to obtain species names using a classical DNA barcoding approach (Boyer et al. 2011). DNA was extracted using the GF-1 tissue DNA extraction kit (Vivantis Technologies) following the manufacturer's recommendations. DNA amplification was performed using the GoTaq ${ }^{\mathbb{R}}$ Green Master Mix (Promega) following the protocol described by Lefort et al. (2012), using the universal COI primers of Folmer (1994). Each $10 \mu \mathrm{l}$ PCR reaction contained $5 \mu \mathrm{l} \mathrm{GoTaq}{ }^{\circledR}$ Green Master Mix, $0.5 \mu$ l of forward and reverse primers $(10 \mu \mathrm{M}), 1.5 \mu 1$ of DNA template, and 3 $\mu \mathrm{l}$ of nuclease-free water. Many New Zealand earthworms have not been morphologically described, and only few species have been barcoded before (Boyer et al. 2011). Any megascolescid earthworm for which the DNA sequence had no match in Genbank and in our local library (Waterhouse et al. 2014) was considered an unknown endemic and was classified in a Molecular Taxonomic Unit (MOTU) grouping.

Beetles were identified to the level of family using May (1993) and family richness was calculated for each sample. We used beetle diversity as a simple metric for comparison of invertebrate biodiversity within and outside the reserve; use of higher taxonomic richness has been advocated as a valuable and rapid surrogate for biodiversity when specimens cannot be identified easily to species level (Balmford et al. 1996; Hodge \& Frampton 2001). Spiders were identified using Paquin et al. (2010) and Vink (2002) and by comparison to specimens in the Lincoln University Entomology Research Museum. The only spider obtained in numbers suitable for subsequent statistical analysis was the native wolf spider Anoteropsis hilaris.

\section{Statistical Analyses}

Data were analysed using Genstat v14 software, with most response variables being analysed by nested ANOVA, with the primary explanatory factors defined as ground elevation and sample location ('inside' or 'outside') the reserve. None of the response variables exhibited clear linear relationships, or standard non-linear relationships, with distance from the fence-line. Therefore, distance into the reserve was treated as a categorical explanatory factor, nested within sample location.

Soil nutrient measurements, exotic earthworm abundance, beetle abundance and beetle diversity were transformed as $\log _{10}(\mathrm{x}+1)$ to help meet the requirements of the analysis, such as normality of residuals and homogeneity of variances. Similarly, species richness and ground cover of native and exotic plants in each quadrat were transformed as $\log _{10}$ $(\mathrm{x}+1)$. The data for native earthworms and native shrubs were dominated by zero counts and were therefore transformed to binary presence/absence data and analysed using generalised linear models.

\section{Results}

\section{Soil properties}

The $\mathrm{pH}$ of the soil samples ranged between 4.30 and 6.91 , and $\mathrm{pH}$ was significantly lower within the reserve (mean 5.4 $\pm 0.6 \mathrm{SD}$ ) than in the pasture paddock (mean $6.1 \pm 0.5 \mathrm{SD}$ ) $\left(F_{1,54}=27.47 ; P<0.001\right)$. Soils in the lower-lying transects tended to be less acidic than those in higher levels (Fig. 2A, $\left.F_{2,54}=22.47 ; P<0.001\right)$.

Mean soil phosphate concentrations (Fig. 2B) were much higher in soil samples taken outside the reserve $\left(F_{1,54}=15.79\right.$; $P<0.001)$, with concentrations decreasing with distance from the fence-line, and with the lower-lying transects containing the highest values of the three elevations $\left(F_{2,54}=14.18\right.$; $P<0.001)$.

Extractable nitrate concentrations (Fig. 2C) were considerably higher in the pasture $\left(F_{1,54}=44.20 ; P<0.001\right)$, decreasing in the reserve with distance from the fence-line $\left(F_{7,54}=2.31 ; P=0.039\right)$, but neither nitrate nor ammonium (Fig. 2D) were affected by the ground level of transects $\left(F_{2,54}\right.$ $=1.39 ; P=0.257$ and $F_{2,54}=2.38 ; P<0.102$ ).

\section{Plant diversity}

The dairy pasture was dominated by the exotic grass Lolium perenne, with some Agrostis capilliaris and clover (Triflolium repens), and no native species apart from small patches of the mosses Hypnum cupressiforme and Breutelia pendula (Table 1). Only $31 \%$ of the native vascular plant species recorded in 1970 were found again in our surveys. More than half of the exotics originally recorded were found again, but 27 new exotic species were observed in the current surveys (Table 1). Four mosses Breutelia pendula, Hypnum cupressiforme, Racomitrium pruinosum (or R. lanuginosum) and $R$. ptycophyllum and two lichens, Cladina aggregata and $C$. confusa were also recorded. Percentage cover of exotic species was high in the reserve (Fig. 3), primarily due to the exotic grass Anthoxanthum odoratum. Beyond the first $10 \mathrm{~m}$ into the reserve, no statistically significant trends of species richness were found along transects $\left(\mathrm{F}_{7,54}=1.13 ; \mathrm{P}=0.360\right)$. There is an obvious buffer zone ( $0-20 \mathrm{~m}$ wide) between the paddock and reserve. Ground elevation did not affect native species richness $\left(F_{2,54}=1.07 ; P=0.351\right)$ and percentage ground cover $\left(F_{2,54}=1.65 ; P>0.202\right)$. However, exotic species richness $\left(F_{2,54}=5.53 ; P=0.007\right)$ and percentage ground cover 

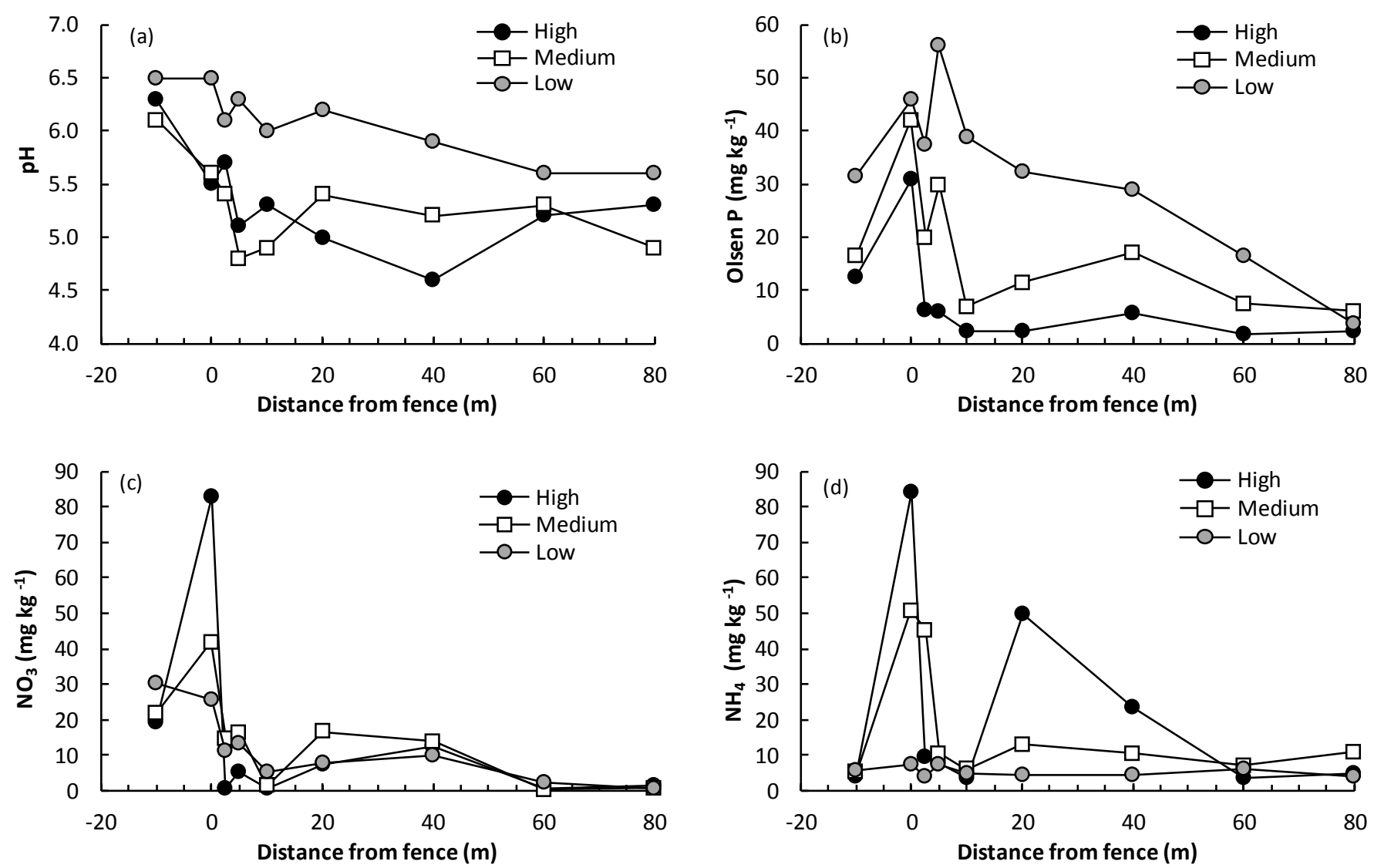

Figure 2. Soil properties along transects from an adjacent dairy pasture $(-10 \mathrm{~m})$ into Bankside Scientific Reserve, at varying distances from the fence-line of a neighbouring dairy farm $(0 \mathrm{~m})$ and in the higher, intermediate and lower elevation transects for (a) $\mathrm{pH}$, (b) $\mathrm{Olsen}$ $\mathrm{P}$, (c) nitrate $\mathrm{NO}_{3}$, (d) ammonium $\mathrm{NH}_{4}$. (mean; $n=3$ ).

Table 1. Number of plants recorded in the three botanical surveys (1970-2013) of Bankside Scientific Reserve.

\begin{tabular}{|c|c|c|c|c|}
\hline & \multicolumn{3}{|c|}{ Year of survey } & \multirow{2}{*}{$\begin{array}{l}\text { Apparent number (and \%) remaining } \\
\text { from } 1970 \text { in the two later surveys }\end{array}$} \\
\hline & 1970 & 2005 & 2013 & \\
\hline \multicolumn{5}{|l|}{ Indigenous plants } \\
\hline No. of families & 30 & 11 & 10 & $13(43 \%)$ \\
\hline No. of species & 65 & 13 & 13 & $20(31 \%)$ \\
\hline \multicolumn{5}{|l|}{ Adventive plants } \\
\hline No. of families & 20 & 13 & 9 & $10(50 \%)^{b}$ \\
\hline No. of species & 36 & 39 & 20 & $20(56 \%)^{\mathrm{a}}$ \\
\hline $\begin{array}{l}\text { Moss \& Lichen } \\
\text { No. of species }\end{array}$ & 48 & - & 6 & $6(13 \%)$ \\
\hline
\end{tabular}

${ }^{\mathrm{a}} 27$ species ( ${ }^{\mathrm{b}} 7$ families) of exotic plants were recorded in the latter two surveys that were not recorded in the 1970 survey. Species and family listings are provided in Supplementary Information.

$\left(F_{2,54}=5.64 ; P=0.006\right)$ were significantly higher in the lower elevation transects.

Of the three common native shrubs in the reserve, kānuka was by far the most abundant (Fig. 3), and was even present just inside the fence-line. Indigenous broom (Carmichaelia australis) was not affected by ground level (GLM deviance ratio, $\mathrm{DR}=1.77 ;$ d.f. $=2 ; P=0.78)$, whereas matagouri showed a tendency to occur in the lower ground transects $(\mathrm{DR}=4.36$; d.f. $=2 ; P=0.013$ ) and kānuka was most commonly found in the middle and high ground and avoided the lower areas (DR $=7.68$; d.f. $=2 ; P<0.001)$. This absence of kānuka from the lower levels of the reserve can be clearly seen in the aerial photograph (Fig. 1).

\section{Earthworms}

Ten species of earthworms were recorded in the current study, including six exotic lumbricid species (Table 2). A number of incomplete worms were also collected but could not be identified. By far the most abundant species was the exotic Aporrectodea caliginosa, which accounted for 386 (70\%) of all specimens collected. Exotic earthworms were affected by distance from the fence-line, being most abundant close to the 


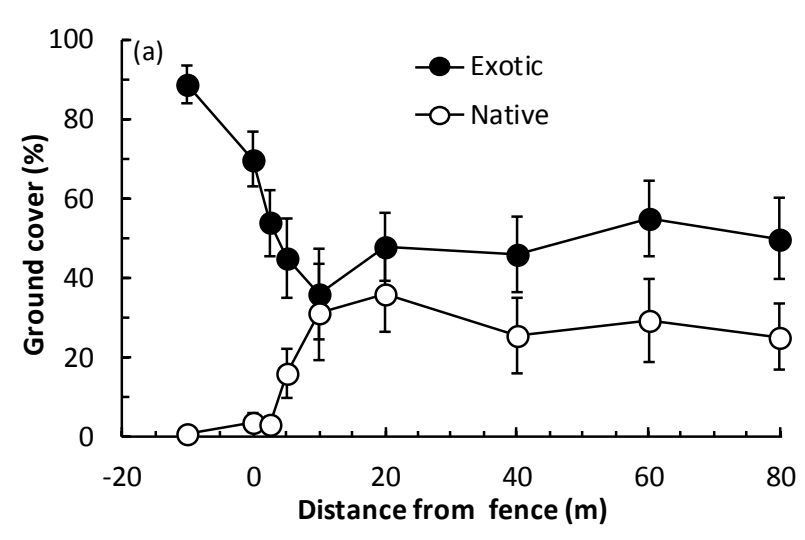

Figure 3. Percentage cover (a) and species richness (b) of exotic and native plants, and density of native shrubs (c) in Bankside Scientific Reserve, at varying distances from the fence-line of a neighbouring dairy farm (mean \pm se; $n=9$ ).
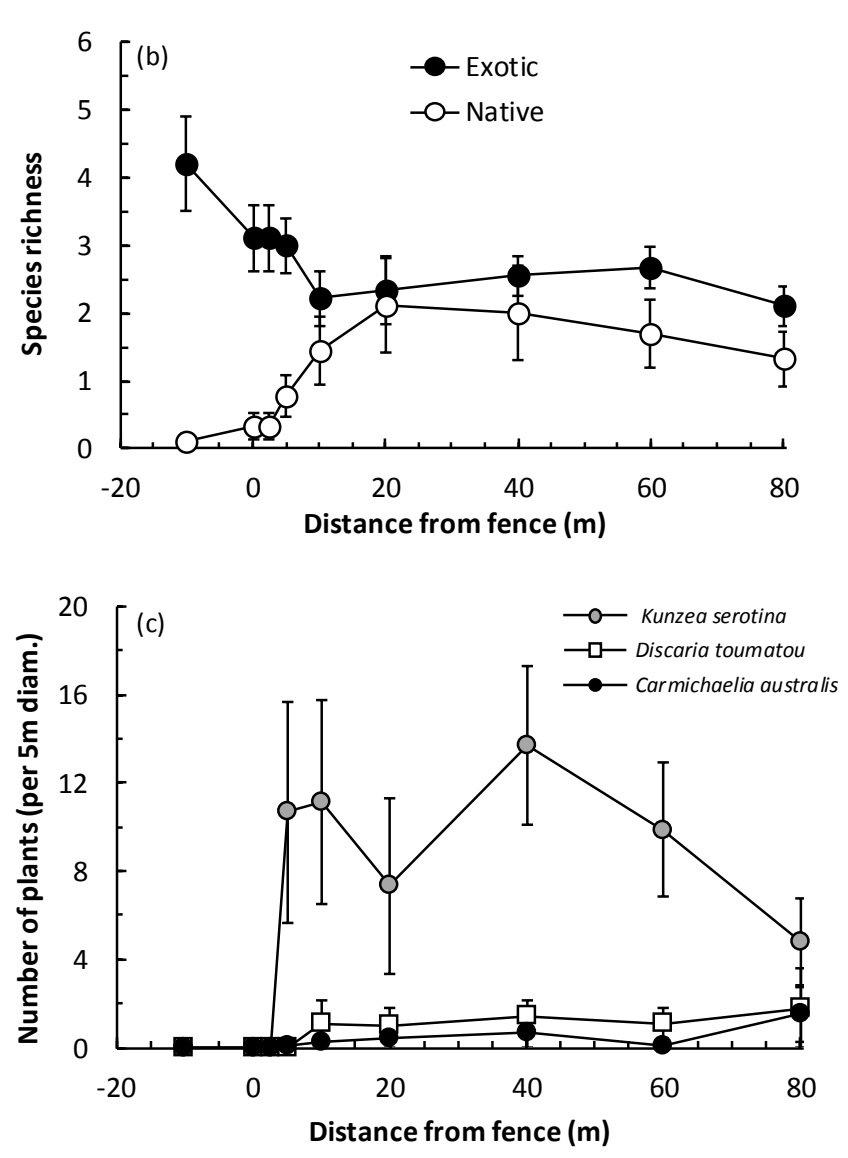

Table 2. Distribution of earthworms in Bankside Scientific Reserve in relation to proximity to the fence-line of a neighbouring dairy farm. Values are total counts in nine $20 \mathrm{~cm}^{3}$ soil samples. All Megascolescidae were genetically close to known endemic species (less than 3\% difference based on COI primers) and were therefore classified as endemic earthworms and given a Molecular Taxonomic Unit (MOTU) code. A number of incomplete worms were also collected but could not be identified and were classified as 'Unidentified'. The bottom row indicates species richness at distances from fence-line.

\begin{tabular}{|c|c|c|c|c|c|c|c|c|c|c|c|}
\hline & \multirow[b]{2}{*}{ Species } & \multicolumn{9}{|c|}{ Distance from fence-line (m) } & \multirow[b]{2}{*}{ Total } \\
\hline & & -10 & 0 & 2.5 & 5 & 10 & 20 & 40 & 60 & 80 & \\
\hline \multirow{6}{*}{$\begin{array}{l}\text { Exotic } \\
\text { (Lumbricidae) }\end{array}$} & Aporrectodea caliginosa & 59 & 52 & 96 & 60 & 54 & 31 & 4 & 21 & 9 & 386 \\
\hline & Aporrectodea rosea & - & - & - & 1 & - & 3 & 1 & - & - & 5 \\
\hline & Aporrectodea trapezoides & 21 & 1 & 11 & - & 3 & - & 1 & 6 & 1 & 44 \\
\hline & Dendrobaena octaedra & - & - & 8 & 4 & 6 & - & - & - & 1 & 5 \\
\hline & Lumbricus rubellus & 1 & 4 & 11 & 10 & 3 & 2 & - & 5 & 2 & 38 \\
\hline & Unidentified Lumbricidae & - & - & 4 & 2 & - & - & - & 1 & - & 7 \\
\hline \multirow{5}{*}{$\begin{array}{l}\text { Native } \\
\text { (Megascolescidae) }\end{array}$} & MOTU 1 & - & - & - & - & - & 7 & - & - & - & 7 \\
\hline & MOTU 2 & - & - & - & - & - & - & 1 & - & - & 1 \\
\hline & MOTU 3 & - & - & - & 2 & 1 & 4 & 1 & 2 & 4 & 14 \\
\hline & MOTU 4 & - & - & - & - & - & - & - & - & 5 & 5 \\
\hline & Unidentified Megascolescidae & - & 1 & 5 & 2 & 3 & 3 & 4 & 4 & 5 & 27 \\
\hline Species richness & & 3 & 4 & 6 & 7 & 6 & 6 & 6 & 6 & 7 & \\
\hline
\end{tabular}

fence-line with numbers decreasing further into the reserve $\left(F_{7,54}=2.28 ; P=0.042\right)$ (Fig. 4). Exotic earthworms were also significantly more abundant in the lower-lying ground areas compared to the middle and high ground $\left(F_{2,54}=12.19\right.$; $P<0.001)$.

Only 26 individuals belonging to four native megascolescid earthworm species were recorded, and three of these species were each only observed in a single sample from the 81 soil samples. The data for the native earthworms were dominated by zero counts, but the specimens were all found within the confines of the reserve ( $\mathrm{DR}=4.57$ for 1 d.f.; $P=0.037$ ) (Table 2 ). There was some indication that the presence of native species may be affected by ground level, being relatively infrequent in the low-lying ground ( $\mathrm{DR}=3.00$ for 2 d.f.; $P=0.058$ ). Overall earthworm species richness exhibited a positive relationship with distance from the fence-line, due to the combination of native and the more ubiquitous exotic species (Table 2). 


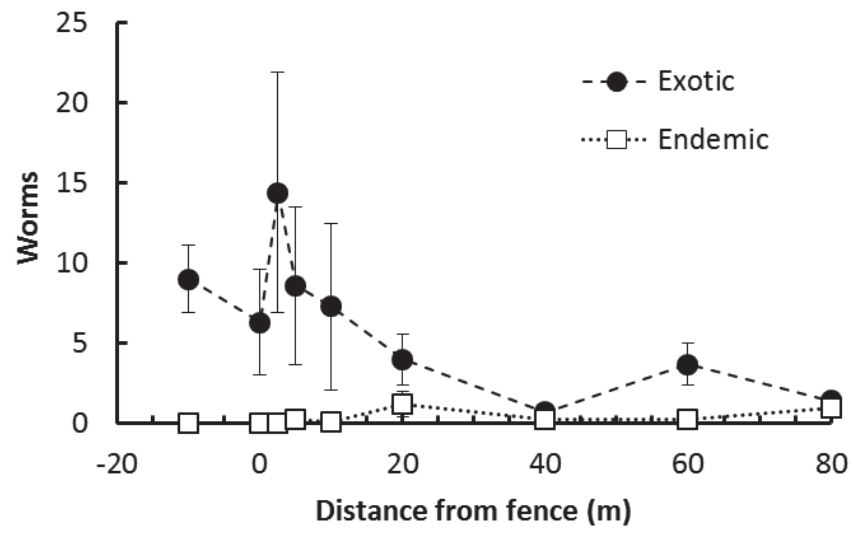

Figure 4. Abundance of exotic and native earthworms in Bankside Scientific Reserve at varying distances from the fence-line of a neighbouring dairy farm (mean \pm se; $n=9$ )

\section{Ground invertebrates}

Overall, 112 specimens (mostly larvae) of Coleoptera were recorded belonging to six families: Carabidae, Chrysomelidae, Curculionidae, Elateridae, Scaraeibidae, and Staphylinidae. There were no significant relationships between Coleoptera abundance or taxonomic richness with ground level or location within the reserve (Table $3 ; P>0.14$ in all cases). Three spider species were identified from the soil in the reserve: the golden brown jumping spider (Trite auricoma), the trap door spider (Cantuaria dendyi), and the native wolf spider (Anoteropsis hilaris), the last being the only species recorded in sufficient numbers to statistically analyse ( 30 specimens collected). The presence of this species was significantly affected by ground level, with no specimens recorded in low-lying transects (DR $=7.86$ for 2 d.f.; $P<0.001$ ); however, there was no indication its occurrence was greater either within the reserve or the pasture (Table 3; DR $=0.74$ for 1 d.f.; $P=0.391$ ). A single immature specimen of ground wētā (Hemiandrus sp.) was also collected, but was too small to identify to species level.

\section{Discussion}

\section{Soil properties}

Prior to land clearance and conversion to agriculture, the shallow, well-drained and stony soils would have been of an acidic and low nutrient status. (McClaren \& Cameron 1996; Molloy 1998), with $\mathrm{pH}$ probably c. 4.5 , as seen in the higher elevations within the reserve. Typically, this had been raised to 6.3 in the farmed paddock through liming, and this has clearly impacted on the lower-lying areas of the reserve (Fig. 2A). This suggests a buffering effect through transport of solutes in drainage water, rather than from windblown fertilisers or other particulates.

Elevated soil nutrients at the fence-line, compared with $10 \mathrm{~m}$ into the pasture, were possibly due to cattle walking, excreting and defecating along the fence-line. Clearly there was marked transfer of phosphorus into the reserve (Fig. 2B). Phosphorus would normally be transported with eroded and mobile soil particles unless applied as soluble superphosphate formulations. Combinations of recycled slurries and superphosphate are common in New Zealand dairy systems. In agricultural terms, Olsen $P$ concentrations measured in the reserve $\left(0.65-67.5 \mathrm{mg} \mathrm{kg}^{-1}\right)$ would suggest a fertile soil in all low elevation samples, except at $80 \mathrm{~m}$. All medium elevation sampling points also clearly had elevated phosphorus fertility. Olsen $\mathrm{P}$ values of $20-30 \mathrm{mg}^{-1}$ are the normal range for medium levels of fertility in agricultural soils in Canterbury (McDowell et al. 2002; Condron \& McDowell 2003). Mean concentrations only fell below this range from the sampling point $10 \mathrm{~m}$ into the reserve, gradually declining to $8.5 \mathrm{mg}$ $1^{-1}$ at $80 \mathrm{~m}$. However, individual soil samples (potentially representing hotspots) were found with Olsen $\mathrm{P}$ above 30 $\mathrm{mg}^{-1}$ at all distances into the reserve, apart from $80 \mathrm{~m}$.

Table 3. Abundance of beetles (Coleoptera) and spiders (Araneae) collected in soil samples in Bankside Scientific Reserve in relation to distance from the fence-line.

\begin{tabular}{|c|c|c|c|c|c|c|c|c|c|c|}
\hline \multirow[b]{2}{*}{ Family or species } & \multicolumn{9}{|c|}{ Distance from fence-line into reserve (m) } & \multirow[b]{2}{*}{ Total } \\
\hline & -10 & 0 & 2.5 & 5 & 10 & 20 & 40 & 60 & 80 & \\
\hline \multicolumn{11}{|l|}{ BEETLES } \\
\hline Staphylinidae & - & 1 & 5 & - & 2 & - & - & 2 & - & 10 \\
\hline Carabidae $^{1}$ & 3 & 1 & 4 & - & - & 1 & - & 1 & 1 & 11 \\
\hline Curculionidae $^{2}$ & 26 & 3 & - & - & 1 & - & - & 3 & - & 33 \\
\hline Elateridae $^{3}$ & - & 5 & 6 & 1 & 1 & - & 3 & 10 & 1 & 27 \\
\hline Chrysomelidae $^{4}$ & - & 1 & - & 5 & - & 1 & - & - & 7 & 14 \\
\hline Scarabidae $^{5}$ & 4 & 1 & 4 & 1 & 2 & - & 3 & 2 & - & 17 \\
\hline Total (beetles) & 33 & 12 & 22 & 10 & 6 & 4 & 9 & 20 & 14 & 130 \\
\hline Taxa (beetles) & 3 & 6 & 5 & 4 & 4 & 3 & 3 & 6 & 4 & \\
\hline \multicolumn{11}{|l|}{ SPIDERS } \\
\hline Anoteropsis hilaris & - & 9 & 13 & - & - & 3 & 1 & 2 & 2 & 30 \\
\hline Other spiders & - & 7 & 1 & - & 1 & - & 1 & 2 & 2 & 14 \\
\hline
\end{tabular}

Main species identified from each family

${ }^{1}$ Anisodactylus binotatus, Haplanister crypticus

${ }^{2}$ Listroderes delaiguei or L. bonariensis

${ }^{3}$ Pyrophorinae indet.

${ }^{4}$ Atrichatus aeneicollis

${ }^{5}$ Costelytra zealandica 
Differences between ground elevations would suggest this did not represent spray drift from phosphate fertiliser application. However, fertiliser granules (lime and/or superphosphate) were often found $20 \mathrm{~m}$ from the boundary in the top turf portion of soil samples collected for earthworm analysis, and are likely to be responsible for the gradual increase of $\mathrm{pH}$ towards the fence-line (Fig. 2A). Spreading of lime or superphosphate usually involves a cloud of fertiliser dust moving with the prevailing wind.

A somewhat surprising result was that there was no difference in nitrate or ammonium with ground level despite the apparent flow of water from the dairy paddock through the depressions that function as water channels into the reserve during wetter parts of the year (Fig. 2C, D). Aerial photographs showing the greening of the grasses in these areas indicate that occasional surface water flow occurs in these channels (Fig. 1). Nitrate $\left(\mathrm{NO}_{3}{ }^{-}\right)$is the most soluble form of this element and might be expected to be most transferable to the reserve through lateral surface water flow. Downward movement of $\mathrm{NO}_{3}{ }^{-}$through this well-drained Eyre soil is also highly likely. A large proportion of the nitrogen will have been applied to the adjacent paddock directly from animals or indirectly through slurries; nitrification of $\mathrm{NH}_{4}$ from this source might be expected to result in increased concentration of $\mathrm{NO}_{3}{ }^{-}$. Disappearance rates through bacterial denitrification are normally associated with anoxic environments, which would be expected to occur only during short periods of winter waterlogging. While this may provide a partial explanation for lack of elevated nitrate in reserve soils, another explanation may be soil sampling during the summer in the present study. This was well after the main pasture growth period and there had been little recent transport of drainage water and nitrate from the paddocks. Soils were very dry and sufficient time may have passed for $\mathrm{NH}_{4}$ to have volatilised or to have been nitrified, and for $\mathrm{NO}_{3}$ to have leached from soils. Eyre soils are known to be vulnerable to high nitrogen leaching, and nitrogen retention in soils is related to particulate organic matter and coarse roots (Di \& Cameron 2002; Franklin 2014), both of which are low in these sandy and gravelly soils. Changed soil conditions appear to have made the reserve less favourable for native species but better suited to invasion by exotic plants.

\section{Plant diversity}

Only a third of the native vascular plants and $20 \%$ of the moss and lichen species recorded by Molloy (1970) were found in the current study and the one by Jensen \& Shanks (2005). Native Asteraceae were particularly vulnerable, with none of the 14 original species found. In contrast, three of the 11 original adventive Asteraceae species were found in our study and we recorded six new species. Overall, the conditions present in the reserve appear to favour colonisation by exotic species.

The two most resilient indigenous species are kānuka and matagouri. Of these, the kānuka would be the most influential in terms of shading the grass and weedy species to encourage other native species to colonise. Unfortunately, the patchiness of kānuka, particularly at the northern end of the reserve, means that exotic grasses and weeds dominate over the less competitive indigenous species.

Our main vegetation sampling was restricted to the midsummer period, but was combined with significant searches at other times. Only 13 of the original 65 indigenous plant species identified by Molloy (1970) were found again, seven of which were also recorded by Jenson \& Shanks (2005) (Table 1 and Tables S1-S3 in online supplementary material).
Combining records from the May sampling by experienced botanists (Jenson \& Shanks 2005) with the current study, a total of 20 species identified by Molloy (31\%) were found again in more recent years. Three new indigenous species were recorded in the two most recent surveys (a likely Coprosma petriei hybrid, Juncus edgariae, and Pteridium aquilinum var. esculentum). The combination of native plant diversity losses and exotic invaders, as well as a few new native species, represents what is termed by Knox \& O'Connor (2008) as a 'novel or emerging ecosystem' and in dire need of conservation. Bankside Scientific Reserve is one of just a few drylands remaining on the Canterbury Plains of which $<60$ ha $(0.5 \%)$ is protected and in need of targeted, innovative programmes to manage these emerging ecosystems so that native species within can survive, if not dominate (Pawson \& Holland 2008).

The last 20 years have seen substantial restoration planting in this type of landscape (Hahner et al. 2014; Dickinson et al. 2014), and field margins with gorse hedgerows and riparian stands of willows are progressively being replaced with native plants (Price 1993; Washington 2002). Native hedgerows contain high native invertebrate biodiversity (Fukuda et al. 2011) and may also provide ecological corridors to and from natural remnants. A study on agrichemicals on field margins by Schmidtz et al. (2014) concluded that prolonged use of fertilisers and pesticides caused significantly reduced species diversity, particularly in smaller and subordinate species, which were outcompeted by taller grass species. They found the impacts of these agrichemicals became stronger over time and led to changes in plant community composition.

\section{Earthworms}

The persistence of native earthworms in a small isolated reserve is notable, in view of their rarity in New Zealand agricultural landscapes. The introduction of exotic grassland and crops, and the disturbance related to burning and ploughing are assumed to be the main causes of their demise (Lee 1961). However, little is known about co-existence or competition between endemic and exotic earthworms in New Zealand, nor of the capacity of exotic earthworms to colonise soils under native habitats. In this study, native species were never observed in the pasture although exotics had infiltrated the reserve, particularly in lower-lying ground. It would appear this is related to changed hydrology and soil chemistry; in wetter and more fertile soils, lumbricids are able to colonise and survive. It is not known whether exclusion of native species is related to competition from exotics or avoidance of modified soils. Although a relatively small number of native earthworms were recorded, they were present in areas least favourable for exotic earthworms, well within the reserve and on higher drier ground.

\section{Ground invertebrates}

We found no indication that beetles and spiders were more abundant or diverse within the reserve. This may be due to the patchiness of the plants and the variable stony nature of the soil throughout the reserve. However, it may reflect insufficient sampling, especially in the number of specimens per sample unit (see Leather et al. 2014). Most of the taxa collected, such as Anoteropsis hilaris and the elaterid beetles, are typical of crop and pasture land in Canterbury (e.g. Sivasubramaniam et al. 1997; Bowie et al. 2003, 2014) and their presence in the reserve may be an artefact of their general abundance in the area. 


\section{Conservation value of the nature reserve}

Protection of the few remaining dryland ecosystems in Canterbury is critical for both the rare plants and native fauna reliant on this habitat. Several plant species listed by Molloy (1970) at Bankside are listed as 'At risk-Declining' (Townsend et al. 2008); these include Pterostylis tristis, Muehlenbeckia ephedroides and Geranium sessiliflorum. Of these, only G. sessiliflorum could be found there today, which highlights the need to conserve this and the few other remaining Canterbury Plains dryland remnants.

The Bankside Scientific Reserve provides above-ground habitat for a significant number of endemic insect species (Butcher et al. 1980; Emberson et al. 2011). Several interesting conservation finds in the reserve include the ground wētā (Hemiandrus sp.) and trap door spider (C. dendyi). A recent survey by Emberson et al. (2011) also found the large rare Staphylinidae Hadrotes wakefieldi and several species of long-horn beetles (Cerambycidae), making this small reserve a significant remnant in terms of conserving indigenous invertebrates found in these rare dryland ecosystems (Emberson et al. 2011).

The majority of native earthworms sampled were immature and unsuitable for identification to species level based on morphological features. DNA barcoding revealed there were four native species, but these were not recognisable from existing databases. Finding new species is not unusual in New Zealand and adds weight to conservationists' fears that species could be lost before we know of their existence (Brockerhoffet al.2008). Although not part of this study, skinks (Leiolopisma sp.) noted by Molloy (1970), were still present and represent an important endemic component of this habitat.

\section{Recommendations for management of Bankside Scientific Reserve}

Surrounded by farmland, Bankside Scientific Reserve is isolated from other remnants and has limited opportunity for import or export of native plant propagules by birds or wind. This lack of connectivity in the landscape is evidenced by the reduced number of native plant species since the first survey of the site. The formation of a bund wall would provide a barrier against drainage water and nutrient transfer, although a bund created by the neighbouring farmer attracted stock to the fence-line and was soon trampled to the same level as the paddock. Therefore, any bund between farmland and the reserve should be fenced (Hahner et al. 2014). Our findings suggest that a buffer zone would be of value around native vegetation remnants adjacent to dairy farms, and this should be at least $10-20 \mathrm{~m}$ wide to reduce the input of irrigation water and nutrients (effluent, urea, lime and superphosphate). Applying fertilisers only during periods with favourable winds, and planting buffer zones around remnants with native species would also be likely to help conserve the native plants and invertebrates within (Aarons \& Gourley 2012).

Although we did not investigate the impact of exotic mammals at the site, some control of the pests observed at Bankside, such as hares (Lepus europaeus) and hedgehogs (Erinaceus europaeus occidentalis), should also be carried out to protect native flora and fauna such as wētā, earthworms, beetles and skinks. Similarly, continued control of woody weed species, such as gorse (Ulex europaeus) and European broom (Cytisus scoparius), would likely improve conditions for native plant species.

\section{Conclusions}

Although the Bankside Scientific Reserve has lost most of the native plant community, it has conservation value for remnant populations of rare endemic earthworms and other invertebrates. The study highlights the importance of soil chemistry in sustaining native plant and invertebrate biodiversity; modification of soils adjacent to dairy farming systems has a clear impact on native plants and animals, while apparently also creating conditions more suited to invasive exotic species. Lime and phosphate fertilisers may represent the main threats to dryland nature reserves in irrigated dairy landscapes. There is no evidence of an influence of nitrogen in the present study, although increased nitrate mobility would be expected during winter and following wet periods. Although elevational differences between highest and lowest contours were $<5 \mathrm{~m}$ in the present study, the higher areas are immensely significant in avoiding environmental modification from agricultural drainage and effluents, maintaining environmental conditions that most closely resemble the original habitat, and thus providing the most appropriate habitat for native plants and animals.

\section{Acknowledgements}

We thank The Royal Society of New Zealand for a Primary Science Teacher Fellowship for L.B. and Environment Canterbury and Selwyn District Council for providing research funding. Ross Carter-Brown, Monique Wright, Sam Brown, Vikki Smith, Brad Case, Carol Jensen, Alison Shanks, Anita Spencer, Nick Head and Allan Fife provided valuable advice and assistance. The Department of Conservation provided permission to access the reserve and Garth Jansen to access and sample his farmland.

\section{References}

Aarons SR, Gourley CJP 2012. The role of riparian buffer management in reducing off-site impacts from grazed dairy systems. Renewable Agriculture and Food Systems 28: $1-16$.

Agriculture and the New Zealand Economy 2014.http://www. mpi.govt.nz/agriculture (accessed August 2014).

Ballantine DJ, Davies-Colley RJ 2013. Nitrogen, phosphorus and E. coli loads in the Sherry River, New Zealand. New Zealand Journal of Marine and Freshwater Research 47: 529-547.

Balmford A, Green MJB, Murray MG 1996. Using highertaxon richness as a surrogate for species richness: I. Regional tests. Proceedings of the Royal Society of London B 263: 1267-274.

Blakemore LV, Searle PL, Daly BK 1987. Methods for chemical analysis of soils. New Zealand Soil Bureau Scientific Report 80. Lower Hutt, Department of Scientific and Industrial Research. 103 p.

Bowie MH, Marris JWM, Emberson RM, Andrew IG, Berry JA, Vink CJ, White EG, Stufkins MAW, OliverEHA, Early JW, Klimaszewski J, Johns PM, Wratten SD, Mahlfeld K, Brown B, Eyles AC, Pawson SM, Macfarlane RP 2003. A biodiversity inventory of Quail Island (Otamahua): towards the restoration of an invertebrate community. 
New Zealand Natural Sciences 28: 81-109.

Bowie MH, Klimaszewski J, Vink CJ, Hodge S, Wratten SD, 2014. The effect of boundary type and season on the predatory arthropods associated with field margins on New Zealand farmland. New Zealand Journal of Zoology 41: 268-284.

Boyer S, Wratten SD 2010. Using molecular tools to identify New Zealand endemic earthworms in a mine restoration project. Zoology in the Middle East 2: 31-40.

Boyer S, Wratten SD 2011. An integrative taxonomic approach to the identification of three new New Zealand endemic earthworm species (Acanthodrilidae, Octochaetidae: Oligochaeta). Zootaxa 2994: 21-32.

Bretherton G, Given G, 2002. A survey of kanuka (Kunzea ericoides) plant communities in the Eyrewell district. Isaac Centre for Nature Conservation Report 1. Lincoln, New Zealand, Isaac Centre for Nature Conservation, Lincoln, University. $25 \mathrm{p}$.

Brockerhoff E, Pawson SM, Dungan R, Sarfati M, Bowie MH, Wratten SD 2008. Terrestrial Invertebrates. In: Winterbourn M, Knox G, Burrows C, Marsden I eds The natural history of Canterbury. Christchurch, New Zealand, Canterbury University Press. Pp. 493-548.

Butcher MR, Early JE, Emberson RM, Muir CA, 1980. Bankside Scientific Reserve: Entomological Survey 1978-1979. Report for Department of Lands and Survey, Lincoln College, Canterbury. 9 p.

Clark DA, Caradus JR, Monaghan RM, Sharp P, Thorrold BS 2007. Issues and options for future dairy farming in New Zealand. New Zealand Journal of Agricultural Research 50: 203-221.

Condron LM, McDowell R 2003. Phosphorus transfer in agroecosystems. In: Currie LD, Hanly JA eds Tools for nutrient and pollutant management. Occasional Report 17. Fertilizer and Lime Research Centre, Massey University, New Zealand. pp. 75-87.

Di HJ, Cameron KC 2002. Nitrate leaching and pasture production from different nitrogen sources on a shallow stony soil under flood-irrigated dairy pasture. Australian Journal of Soil Research 40: 317-334.

Dickinson N, Marmiroli M, Das B, McLaughlin D, Leung D, Robinson B 2014. Endemic plants as browse crops in agricultural landscapes of New Zealand. Agroecology and Sustainable Food Systems 38: 224-242.

Ecroyd CE, Brockerhoff EG 2005. Floristic changes over 30 years in a Canterbury Plains kanuka forest remnant, and comparison with adjacent vegetation types. New Zealand Journal of Ecology 29(2): 279-290.

Emberson R, Syrett P, Groenteman R 2011. Bankside Scientific Reserve - an important refuge for Canterbury's dryland insect fauna. Weta 41: 4-26.

Folmer O, Black M, Hoeh W, Lutz R, Vrijenhoek R 1994. DNA primers for amplification of mitochondrial cytochrome $\mathrm{c}$ oxidase subunit I from diverse metazoan invertebrates. Molecular Marine Biology and Biotechnology 3(5): 294-299.

Franklin HM 2014. The interaction of New Zealand native plants with nitrogen in Canterbury's agricultural landscapes. PhD thesis, Lincoln University, New Zealand.

Fukuda Y, Moller H, Burns B 2011. Effects of organic farming, fencing and vegetation origin on spiders and beetles within shelterbelts on dairy farms. New Zealand Journal of Agricultural Research 54: 155-176.

Hahner JL, Robinson BH, Hong-Tao Z, Dickinson NM
2014. The phytoremediation potential of native plants on New Zealand dairy farms. International Journal of Phytoremediation 16: 719-734.

Head N, Given D 2001. Threatened plants of Canterbury including a revised species list. Journal of Canterbury Botanical Society 35: 5-14.

Hodge S, Frampton C. 2001. Using higher taxa to estimate species richness: birds on New Zealand islands. Ibis 143: 146-148.

Houlbrooke DJ, Horne DJ, Hedley MJ, Hanly JA, Snow VO 2004. A review of literature on the land treatment of farm-dairy effluent in New Zealand and its impact on water quality. New Zealand Journal of Agricultural Research 47(4): 499-511.

Jenson C, Shanks A 2005. Checklist of plant species from Bankside Scientific Reserve. Unpublished report to Department of Conservation.

Keesing V, Wratten SD 1998. Indigenous invertebrate components in ecological restoration in agricultural landscapes. New Zealand Journal of Ecology 22(1): 99-104.

Knox GA, O'Connor KF 2008. Progress and prospects in ecological restoration. In: Winterbourn M, Knox G, Burrow, C, Marsden I eds The natural history of Canterbury. Christchurch, New Zealand, Canterbury University Press. Pp. 819-846.

Leather SR, Basset Y, Didham RK 2014. How to avoid the top ten pitfalls in insect conservation and diversity research and minimise your chances of manuscript rejection. Insect Conservation and Diversity 7: 1-3.

Lee K 1961. Interactions between native and introduced earthworms. Proceedings of the New Zealand Ecological Society 8: 60-62.

Lee KE 1959. A key for the identification of New Zealand earthworms. Soil Bureau Publication 172: 13-60.

Lefort M-C, Boyer S, Worner SP, Armstrong K 2012. Noninvasive molecular methods to identify live scarab larvae: an example of sympatric pest and nonpest species in New Zealand. Molecular Ecology Resources 12:389-395.

May BM 1993. Larvae ofCurculionoidea(Insecta: Coleoptera): a systematic overview. Fauna of New Zealand 28. Lincoln Manaaki Whenua Press, Lincoln. 226 p.

McClaren RG, Cameron KC 1996. Soil science: sustainable production and environmental protection. Auckland, Oxford University Press. 314 p.

McDowell RW, Condron LM, Mahieu N, Brookes PC, Poulton PR, Sharpley AN 2002. Analysis of potentially mobile phosphorus in arable soils using solid state nuclear magnetic resonance. Journal of Environmental Quality 31: 450-456.

Meurk C, Bellingham PJ, Macmillan B 1995. The last kanuka landscape on the Canterbury Plains. Canterbury Botanical Society Journal 29: 11-24.

Meurk CD 2008. Vegetation of the Canterbury Plains and downlands. In: Winterbourne M, Knox G, Burrows C, Marsden I eds The natural history of Canterbury. Christchurch New Zealand, Canterbury University Press. Pp. 195-250.

Meurk CD, Swaffield SR 2000. A landscape ecological framework for indigenous regeneration in rural New Zealand-Aotearoa. Landscape and Urban Planning 50: $129-144$.

Molloy BPJ 1970. Bankside - a new scientific reserve on the Canterbury Plains. Proceedings of the New Zealand 
Ecological Society 17: 47-51

Molloy L 1998. Soils in the New Zealand Landscape: The Living Mantle. 2nd edn. Cambridge University Press.253 p.

Paquin P, Vink CJ, Dupérré N 2010. Spiders of New Zealand: Annotated Family Key and Species List. Lincoln, Manaaki Whenua Press, Lincoln, New Zealand.

Pawson E, Holland P2008. People, environment and landscape since the 1840s. In: Winterbourn M, Knox G, Burrows C, Marsden I eds The natural history of Canterbury. Christchurch, New Zealand, Canterbury University Press. Pp. 37-64.

Price LW 1993. Hedges and shelterbelts on the Canterbury Plains, New Zealand: transformation of an antipodean landscape. Annals of the Association of American Geographers 83(1): 119-140.

Sivasubramaniam W, Wratten SD, Klimaszewski J 1997. Species composition, abundance, and activity of predatory arthropods in carrot fields, Canterbury, New Zealand. New Zealand Journal of Zoology 24: 205-212.

Schmitz J, Hahn M, Brühl CA 2014. Agrochemicals in field margins - an experimental field study to assess the impacts of pesticides and fertilizers on a natural plant community. Agriculture, Ecosystems and Environment 193: 60-69.

Thorburn PJ, Robertson MJ, Clothier BE, Snow VO, Charmley E, Sanderman J, Teixeira E, Dynes RA, Hall, A, Brown H, Howden SM, Battaglia M 2012. Australia and New Zealand perspectives on climate change and agriculture. In: Rosenzweig C, Hillel D eds Agriculture's contributions to climate change solutions: mitigation and adaptation at global and regional scales. Handbook of climate change and sgroecosystems, Vol 2. New York, American Society of Agronomy and Imperial College Press. Pp. 107-141.

Editorial board member: Chris Lusk

Received 7 October 2014; accepted 29 April 2015

\section{Supplementary Material}

Additional supporting information may be found in the online version of this article:

Table S1. Native species of vascular plants recorded in the three surveys in Bankside Scientific Reserve.

Table S2. Adventive species of vascular plants recorded in the three surveys in Bankside Scientific Reserve.

Table S3. Moss and Lichen species recorded in the two surveys in Bankside Scientific Reserve.

The New Zealand Journal of Ecology provides online supporting information supplied by the authors where this may assist readers. Such materials are peer-reviewed and copy-edited but any issues relating to this information (other than missing files) should be addressed to the authors.
Tilman D, Fargione J, Wolff B, D'Antonio C, Dobson A, Howarth R, Schindler D, Schlesinger WH, Simberloff D, Swackhamer D 2001. Forecasting agriculturally driven global environmental change. Science 292: 281-284.

Townsend AJ, de Lange PJ, Duffy CAJ, Miskelly CM, Molloy J, Norton DA 2008. New Zealand threat classification system manual. Wellington, New Zealand, Science \& Technical Publishing, Department of Conservation. 35 p.

Vink C J 2002. Lycosidae (Arachnida: Araneae). Fauna of New Zealand 44: 1-94.

Voice A 1980. Bankside Scientific Reserve Management Plan. Management Plan Series SCR 1. Christchurch, New Zealand, Department of Lands and Survey. 33 p.

Walker S, Price R, Rutledge D, Stephens RTT, Lee WG 2006. Recent loss of indigenous cover in New Zealand. New Zealand Journal of Ecology 30: 169-177.

Ward WT, Harris CS, Schapper HP 1964. Soils and agriculture of Ellesmere County Canterbury, New Zealand. New Zealand Soil Bureau Bulletin 21. Wellington, New Zealand, NZSB.. 81 p.

Washington SM 2002. Restoring What? A socio-cultural exploration of ecological restoration in Christchurch and Canterbury. Unpublished MSc thesis, Lincoln University, Lincoln, New Zealand. 250 p.

Waterhouse BR, Boyer S, Wratten SD 2014. Pyrosequencing of prey DNA in faeces of carnivorous land snails to facilitate ecological restoration and relocation programmes. Oecologia 175: 737-746.

Williams KJ 2005. Native plant communities of the Canterbury Plains. Christchurch, New Zealand, Department of Conservation. $66 \mathrm{p}$.

Winterbourn MJ 2008. Rivers and streams. In: Winterbourn MJ, Knox G, Burrows C, Marsden I eds The natural history of Canterbury. Christchurch, New Zealand, Canterbury University Press. Pp. 580-615. 